\section{Changes in the Physical, Optical, and Thermal Properties of Polyethylene Mulches during Double Cropping}

\author{
Mathieu Ngouajio ${ }^{\mathbf{1}}$ and Jeremy Ernest \\ Department of Horticulture, Michigan State University, Plant and Soil Sciences \\ Building, East Lansing, MI 48824-1325
}

Additional index words. degree-days, infrared transmitting, light transmission, PAR, weathering

\begin{abstract}
In temperate regions, the vegetable growing season is short and plastic mulches are usually left in the field for an entire year when used for double cropping. This work was conducted to study the effect of weathering on the physical, optical, and thermal properties of plastic mulches during double cropping. The design was a randomized complete block with four replications. The mulches were black, grey, infrared transmitting brown (IRT-brown), IRT-green, white, and white-on-black (co-extruded white/black). Tomato was grown the first year and cucumber the following year. The grey mulch degraded substantially during double cropping (only $40 \%$ of bed was covered the second year) and showed an increase in light transmission and a decrease in heat accumulation (degree-days). The black, whiteon-black, white, IRT-brown, and IRT green mulches showed less degradation with $93 \%$, $91 \%, 85 \%, 75 \%$, and $61 \%$ soil cover, respectively. However, their soil warming ability was significantly reduced. These mulches could be used for double cropping to suppress weeds and to reduce inputs associated with plastic purchase, laying, and disposal. However, they may not provide adequate soil warming early in the season for the second crop.
\end{abstract}

Plastic mulches are widely used in outdoor vegetable production to modify soil temperature, conserve water, control weeds, and alter other microclimatological characteristics of the field. Black mulches are the industry standard (Tarara, 2000), but other mulch colors with different optical properties have been developed. These differences in optical properties affect how the plastic mulch modifies the microclimate around the crop (Decoteau et al., 1988; ; Ham et al., 1993; Kasperbauer and Hunt, 1998; Tarara, 2000). Growers can choose plastic mulches with different optical properties to optimally alter the microclimate for their specific crop.

Vegetable growers routinely use the same plastic mulch to grow more than one crop (Hanna, 2000a, 2000b; Hanna et al., 1993). Double cropping reduces grower expenses for mulch and drip irrigation equipment while also reducing the amount of plastic waste (Hanna 2000a, 2000b; Mugalla et al., 1996; Waterer, 2000). In climates with long growing seasons, fall crops can be planted into existing plastic mulched beds after the spring crops are removed (Hanna, 2000a, 2000b; Hanna et al., 1993). In climates with a shorter grow-

Received for publication 22 June 2004. Accepted for publication 27 July 2004. This research was supported by the Michigan Agricultural Experiment Station (MAES), and the Southwest Michigan Research and Extension Center (SWMREC). Thanks to Jim Hancock and Erik Runckle for their critical comments on the early version of this manuscript. We acknowledge Ronald Goldy, Sieglinde Snapp, and Bernard Zandstra for advice in field experiments and Mrs. Dave Francis and Mark Hildebrand for their technical assistance.

${ }^{1}$ To whom reprint requests should be addressed; e-mail ngouajio@msu.edu.
All mulches were laid in May 2002 on 60-cm wide raised beds, using a combined bed shaper and plastic layer. In 2002, fresh-market 'Mountain Spring' tomato (Lycopersicon esculentum Mill.) was transplanted on 30 May into the different colored plastic mulches and grown using drip-irrigation and fertigation. The mulches were left in the field during the winter. In 2003, slicing cucumber 'Greensleeves' (Cucumis sativus L) was seeded into the same beds on 6 June and grown using drip-irrigation and fertigation. The experimental design was a randomized complete block with six plastic mulches and four replications. Individual plots were $5 \mathrm{~m}$ wide and $10 \mathrm{~m}$ long with three beds. All measurements were made on the middle bed.

Plastic integrity measurement (physical properties). On 25 June 2003, plastic integrity was evaluated before planting cucumber. The percentage of soil covered by the plastic film was visually estimated for each plot in the experiment. A scale of $0 \%$ to $100 \%$ was used, with $100 \%$ indicating complete bed cover by the mulch and $0 \%$ indicating that the bed was completely bare. To determine the effect of double cropping on mulch integrity, $5 \%$ soil cover was added to all evaluations to represent crop holes punched during the first growing season.

Yield measurement. In 2002 the tomato plants were harvested six times between 75 $\mathrm{d}$ after planting (DAP) and 112 DAP. Fruit were picked at the breaker stage. In 2003 the cucumber plants were harvested seven times between 56 and 76DAP. Tomato and cucumber fruit were graded based on visual quality and presence of defects. Fruit number and fruit weight were recorded for each grade.

Light transmission measurement. A sample from each film (about $30 \times 30 \mathrm{~cm}$ ) was used for light transmission measurements. The analyses were conducted on new films and on used films after about 75 and $390 \mathrm{~d}$ of field exposure. Samples from the field were rinsed with distilled water. Their fragility permitted no further cleaning activities. Light transmission in the 400 to $1100 \mathrm{~nm}$ range at $1 \mathrm{~nm}$ increments was measured using a LI1800 spectroradiometer (LI-COR, Lincoln, Neb.) (Brault et al., 2002; Decoteau et al., 1988; Ham et al., 1993; Ngouajio and Ernest, 2004). The light source was an incandescent bulb (2002 samples, $60 \mathrm{~W}$, General Electric Co., Cleveland, Ohio; 2003 samples, $100 \mathrm{~W}$, Philips Lighting Co., Somerset, N.J.) placed $30 \mathrm{~cm}$ from the spectroradiometer. The spectrum of incandescent lamps covers the range of wavelengths measured (Ryer, 1997). Light transmission was determined by the percentage transmission through one layer of plastic compared with a blank scan with no plastic (Brault et al., 2002).

Temperature measurement. Air temperature and temperature under the mulches were recorded at 15-min intervals using data loggers (WatchDog 100-Temp 2K, Spectrum Technologies, Inc., Plainfield, Ill.). Temperature sensors were placed directly under the plastic and at 5 and $10 \mathrm{~cm}$ in the soil profile. Heat accumulation in degree days (DD) was calculated for the air and soil using the following equation: 
Fig. 1. Integrity of colored plastic mulches measured as percentage of bed covered by the mulches after 1 year of field exposure. Means with the same letter are not significantly different (LSD 0.05).

$\mathrm{DD}=1 / 2 \times\left(\mathrm{T}_{\text {Max }}+\mathrm{T}_{\text {Min }}\right)-\mathrm{T}_{\text {base }}$

where $\mathrm{T}_{\mathrm{Max}}, \mathrm{T}_{\mathrm{Min}}$, and $\mathrm{T}_{\text {base }}$ are the daily maximum, the daily minimum, and the base $\left(10^{\circ} \mathrm{C}\right)$ temperatures, respectively (Ibarra et al., 2001; Jenni et al., 1996).

\section{Results}

Plastic integrity. The mulches degraded significantly following a year of exposure in the field (Fig. 1). The black and white/black plastics maintained $>90 \%$ coverage of the soil. The white mulch covered $85 \%$ of the soil. The two IRT mulches both degraded substantially with the brown and green mulches covering only $75 \%$ and $61 \%$ of the soil, respectively. The grey mulch degraded the most and covered only $41 \%$ of the bed.

Heat accumulation. Heat accumulation was measured during the first $30 \mathrm{~d}$ after planting in 2002 and 2003. Soil warming early in the season is a major reason for using plastic mulches in temperate regions. Air temperature after planting was cooler in 2003 compared with 2002 (Fig. 2, Table 1). A total of 427 and 410 DD accumulated the first $30 \mathrm{~d}$ after planting in 2002 and 2003, respectively (Table 1). This corresponds to about $4 \%$ reduction in air DD between 2002 and 2003.

In 2002, all mulches accumulated substantially more DD than the air at all soil depths (Fig. 2, Table 1). Soil temperature under the black and the two IRT mulches was the warmest, accumulating 647 to 665,569 to 594 , and 553 to $564 \mathrm{DD}$ at 0,5 , and $10 \mathrm{~cm}$, respectively. These were followed by the grey, the white/black, and the white mulch.

In 2003, after a year in the field, a substantial reduction in the warming ability of the mulches was observed, especially at 5 and $10 \mathrm{~cm}$ soil depths (Fig. 2, Table 1). The DD accumulated in the soil were closer to air DD as compared with year 2002 when the mulches were newly installed. The warmest plastic in 2003 was the IRT green.

Light transmission. The white mulch transmitted the greatest amount of light, with $46 \%$ in 2002 and $37 \%$ in 2003 (Fig. 3, Table 2). The two IRT mulches transmitted a substantial amount of light in the 800 to $1100 \mathrm{~nm}$ range (35\% to $45 \%$ ), but far less in the photosynthetically active range of 400 to $700 \mathrm{~nm}(8 \%$ to $12 \%)$. All plastics transmitted less light after a year of field exposure (Fig. 4, Table 2). The reduction in transmission was greatest in the PAR waveband ( 400 to $700 \mathrm{~nm}$ ) and was somewhat less at longer wavelengths. When new, the grey plastic transmitted about $16 \%$ of light across the entire spectrum measured. Unlike the white and IRT plastics, as the field exposure of the grey plastic increased, the light transmission also increased, especially at longer wavelengths (Figs. 3 and 4). The black and white/black plastics transmitted very little light $(0 \%$ to $2 \%)$ either when new or after field exposure.

Fig. 2. Heat accumulation measured as air or soil $(0,5$, $10 \mathrm{~cm}$ ) degree-days (DD) under colored mulches during the first $30 \mathrm{~d}$ following crop planting in 2002 and 2003 growing seasons.
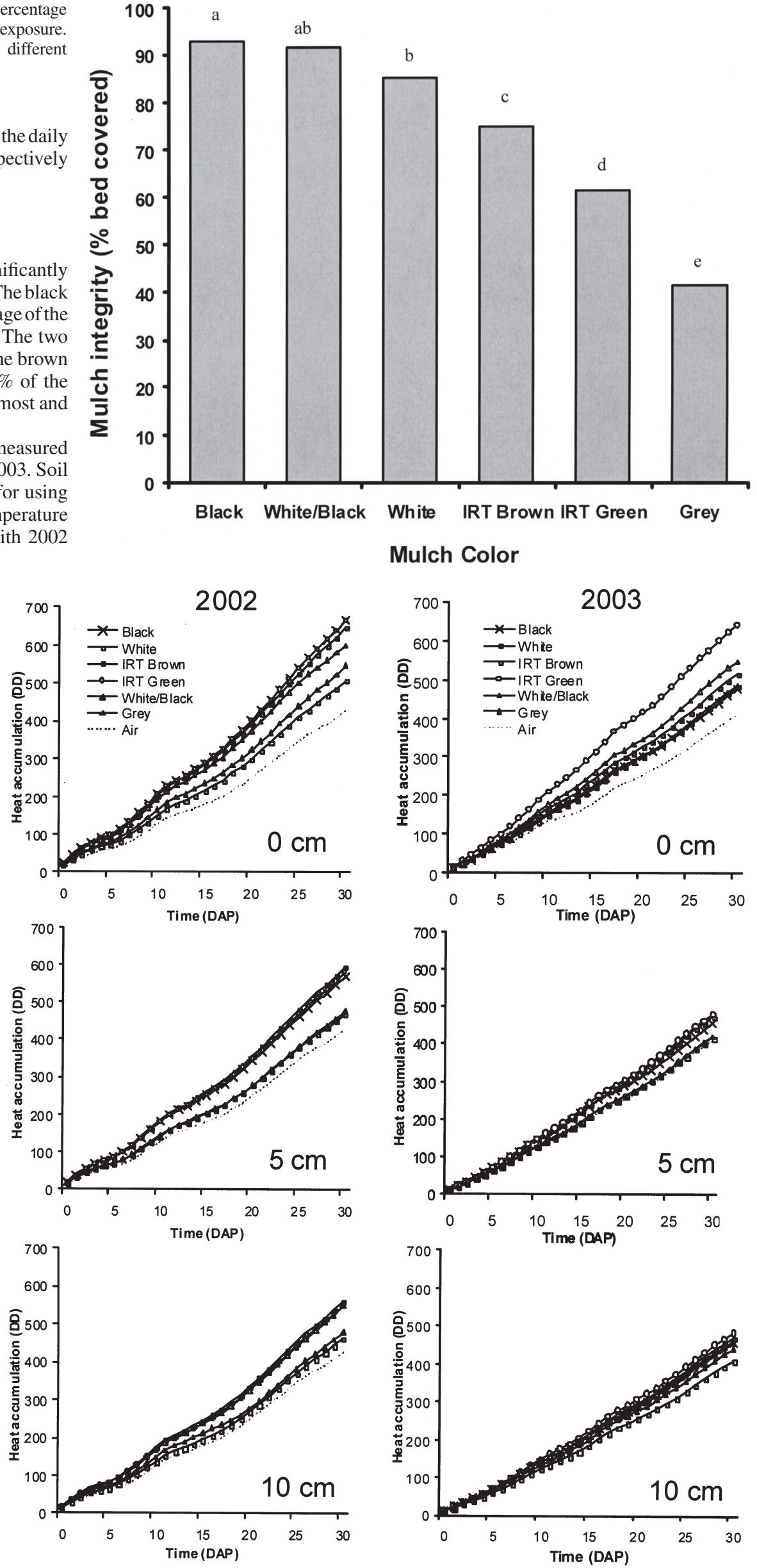
Table 1. Heat accumulation during the first $30 \mathrm{~d}$ measured as air or soil $(0,5,10 \mathrm{~cm})$ degree-days (DD) under colored mulches.

\begin{tabular}{|c|c|c|c|c|c|c|}
\hline \multirow[b]{3}{*}{ Mulch color } & \multicolumn{6}{|c|}{ Heat accumulation (DD) } \\
\hline & \multicolumn{3}{|c|}{2002} & \multicolumn{3}{|c|}{2003} \\
\hline & $0 \mathrm{~cm}$ & $5 \mathrm{~cm}$ & $10 \mathrm{~cm}$ & $0 \mathrm{~cm}$ & $5 \mathrm{~cm}$ & $10 \mathrm{~cm}$ \\
\hline White & 507 & 469 & 467 & $482\left(95 \%^{z}\right)$ & $417(89 \%)$ & $409(88 \%)$ \\
\hline Black & 665 & 569 & $\mathrm{NA}^{\mathrm{y}}$ & $475(71 \%)$ & $455(80 \%)$ & 457 (NA) \\
\hline White/black & 547 & 475 & 481 & $485(89 \%)$ & $419(88 \%)$ & $441(92 \%)$ \\
\hline Grey & 599 & NA & 550 & $548(91 \%)$ & NA (NA) & $460(84 \%)$ \\
\hline IRT green & 664 & 581 & 553 & $640(96 \%)$ & $480(83 \%)$ & $483(87 \%)$ \\
\hline IRT brown & 647 & 594 & 564 & $516(80 \%)$ & $475(80 \%)$ & $471(84 \%)$ \\
\hline Air & 427 & & & $410(96 \%)$ & & \\
\hline
\end{tabular}

${ }^{2} 2003$ heat accumulation as a percent of 2002 heat accumulation.

${ }^{y} \mathrm{NA}=$ not available. IRT $=$ infrared transmitting. Some data loggers failed during the course of the season.

Table 2. Light transmission through new colored plastic mulches and mulches during the first and the second growing season.

\begin{tabular}{|c|c|c|c|c|c|c|}
\hline \multirow[b]{3}{*}{ Mulch color } & \multicolumn{6}{|c|}{ Light transmission $(\%)^{z}$} \\
\hline & \multicolumn{2}{|c|}{$\begin{array}{l}\text { New } \\
\text { plastic }\end{array}$} & \multicolumn{2}{|c|}{$\begin{array}{l}\text { After first season } \\
\text { August } 2002\end{array}$} & \multicolumn{2}{|c|}{$\begin{array}{c}\text { During second season } \\
\text { June } 2003 \\
\end{array}$} \\
\hline & PAR & Total & PAR & Total & PAR & Total \\
\hline White & 40.73 & 45.79 & 34.64 & 42.67 & 27.76 & 37.45 \\
\hline Black & 0.03 & 0.04 & 0.00 & 0.01 & 0.00 & 0.01 \\
\hline White/black & 0.88 & 1.55 & 0.76 & 1.68 & 0.68 & 1.26 \\
\hline Grey & 15.63 & 16.31 & 16.55 & 18.62 & 19.10 & 21.92 \\
\hline IRT green & 11.67 & 30.77 & 11.96 & 35.88 & 9.21 & 26.92 \\
\hline IRT brown & 7.49 & 22.28 & 6.68 & 24.73 & 5.28 & 16.20 \\
\hline
\end{tabular}

${ }^{2}$ Light transmission is the average for wave lengths 400 to $1100 \mathrm{~nm}$ (total) or the average for photosynthetically active radiation $(\mathrm{PAR}=400$ to $700 \mathrm{~nm})$. IRT $=$ infrared transmitting
The average tomato yield in 2002 was 52 to $63 \mathrm{t} \cdot \mathrm{ha}^{-1}$ and cucumber yield in 2003 , was about 15 to $20 \mathrm{t} \cdot \mathrm{ha}^{-1}$ (Table 3 ). However, yield for most of the mulch treatments were not significantly different.

\section{Discussion}

The success of double cropping of plastic mulches for vegetable production in regions with a single short growing season requires that
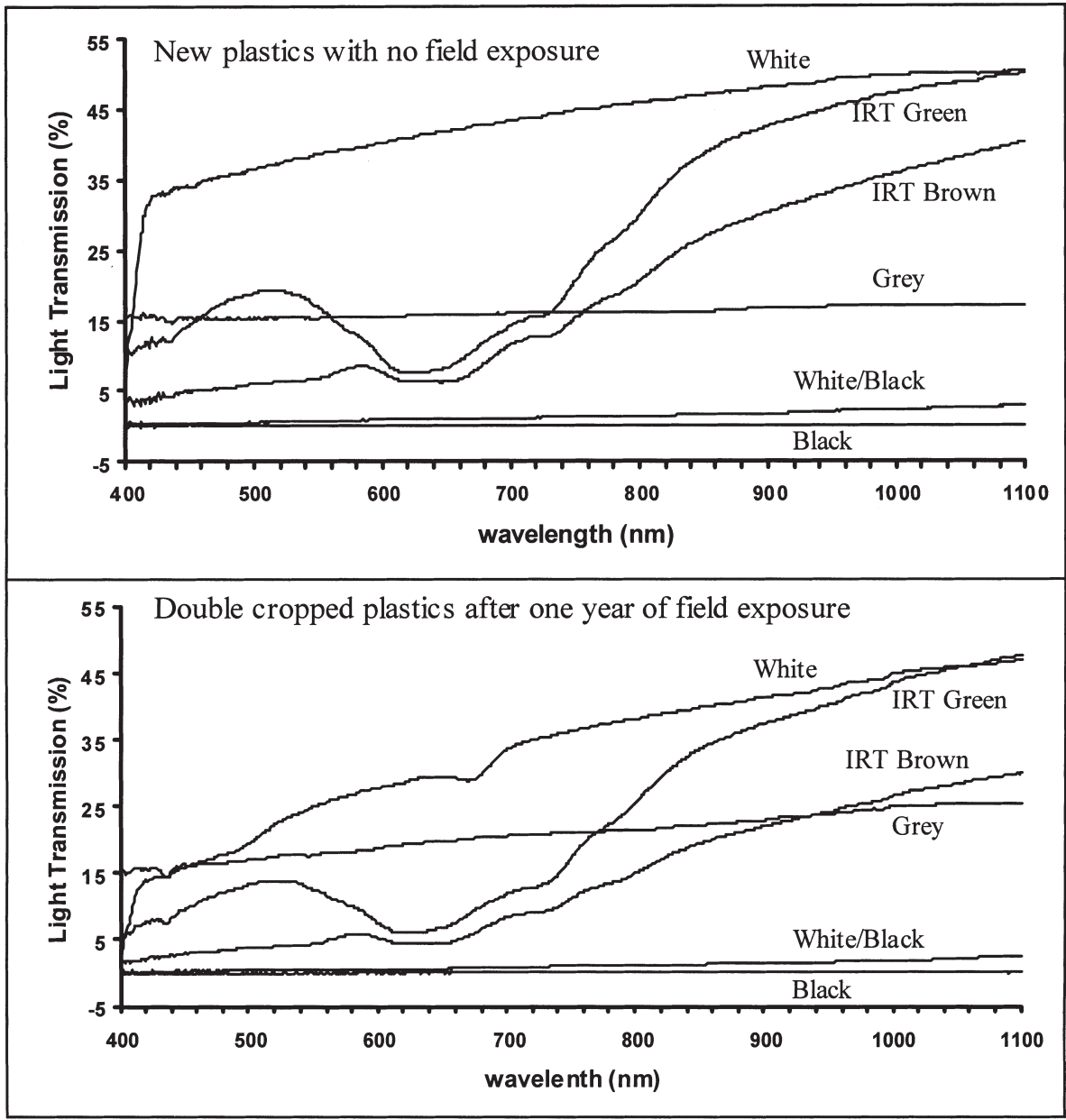

the mulches maintain their physical, optical, and thermal properties. Adequate soil cover and low light transmission in the PAR region of the spectrum are essential for acceptable weed suppression (Ngouajio and Ernest, 2004). Additionally, the mulches should be able to warm the soil early in the season to promote growth and yield.

In this study, the grey mulch degraded extensively during double cropping and only $40 \%$ of the bed was covered with the mulch at crop planting the second year. Unlike all of the other mulches, the grey mulch allowed more light to pass through in 2003 than in 2002 (Fig. 4). Jones and Chapman (1968) and Maelzer (1986) indicated that mulches should cover at least $50 \%$ to $60 \%$ of the soil to be effective. Heavy weed infestations were observed in the grey mulch treatment (data not shown). However, all plots were weeded regularly to avoid the confounding effects of weeds on crop yield.

The black, white/black, and the white mulches maintained over $85 \%$ soil cover after a year in the field (Fig. 1) but showed a reduction in light transmission during double cropping (Fig. 4). These films could therefore maintain their weed suppression ability during double cropping. Their ability to warm the soil early in the season was, however, reduced the second year in excess of the $4 \%$ reduction in air DD recorded in 2003. The mechanism by which black mulch warms the soil is well documented (Tarara, 2000). The black mulch absorbs over $90 \%$ of the solar radiation, which is subsequently conducted to the soil in the form of heat (Ngouajio and Ernest, 2004; Tarara, 2000). Good contact between the mulch and the soil is therefore essential for adequate transfer of the heat (Ham et al., 1993; Liakatas et al., 1986; Tarara, 2000). During double cropping however, the black mulch became loose, a condition that may explain the reduction in its soil warming ability.

If plastic mulches are used solely for water conservation and weed control, black and white/black plastics may be successfully double cropped under Michigan growing conditions. The soil heating capacity of the black plastic would greatly diminish for the second crop, but in certain cases this may actually be beneficial. For example, in regions with long growing season, the second crop may immediately follow the first. The second crop may be planted midsummer when the soil is already sufficiently warm and when additional heating could be detrimental (Díaz-Pérez and Batal, 2002; Hanna, 2000 a, 2000b). However, in regions with a shorter growing season, the second crop is usually planted in the spring of the following year. Under those conditions, the heating capacity of the black mulch may be important thereby reducing the benefits of double cropping the mulch.

Fig. 3. Amount of light (\%) transmitted through new plastic mulches and double cropped mulches after one year in the field. The mulches are black, white, gray, white-on-black (white/black), infrared transmitting green (IRT-green), and infrared transmitting brown (IRT-brown). 


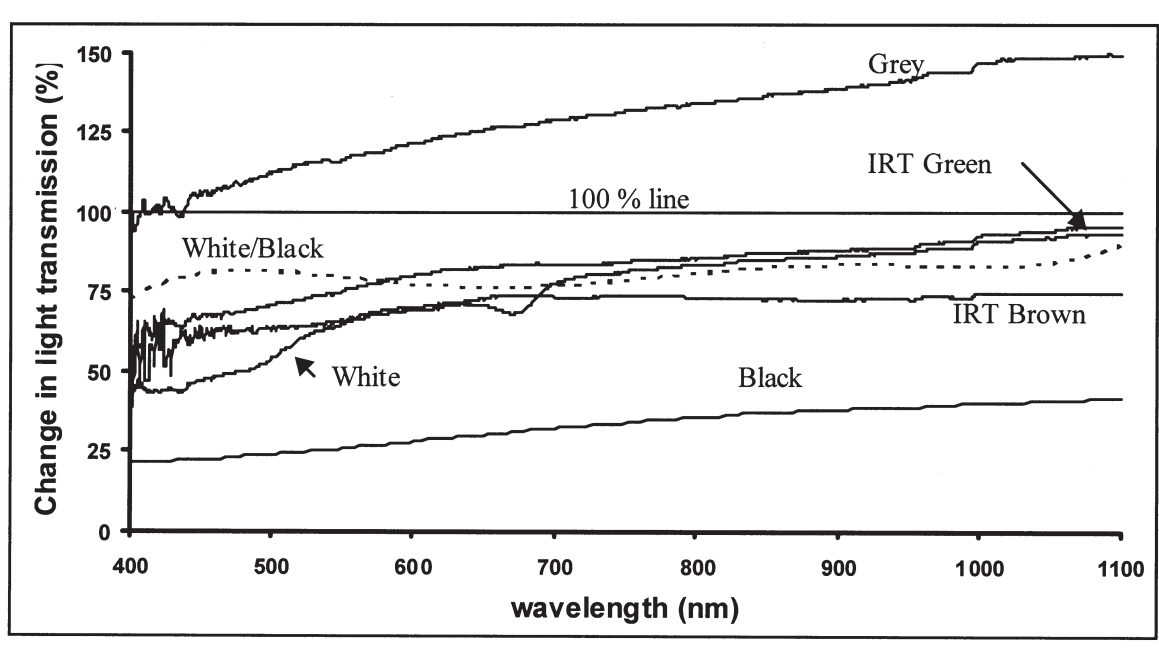

Fig. 4. Change in light transmission of mulches as a result of double cropping. Light transmission through plastic mulches with 1 year of field exposure as a percentage of light transmission through new plastic mulches.

Table 3. Tomato and cucumber yield when grown using colored plastic mulches.

\begin{tabular}{lcc}
\hline & \multicolumn{2}{c}{ Grade-1 fruit yield $\left(\mathrm{t} \cdot \mathrm{ha}^{-1}\right)^{\mathrm{z}}$} \\
\cline { 2 - 3 } $\begin{array}{l}\text { Mulch } \\
\text { color }\end{array}$ & $\begin{array}{c}\text { Tomato } \\
(2002)\end{array}$ & $\begin{array}{c}\text { Cucumber } \\
(2003)\end{array}$ \\
\hline White & 54.9 & 15.2 \\
Black & 52.6 & 18.2 \\
White/black & 52.2 & 18.8 \\
Grey & 58.6 & 18.3 \\
IRT green & 62.8 & 20.4 \\
IRT brown & 57.3 & 19.9 \\
LSD & 10.1 & 9.4 \\
\hline
\end{tabular}

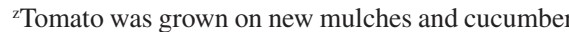
was double cropped the following year.

The IRT green and IRT brown provided 61 and $75 \%$, respectively, of soil cover the second year (Fig. 1). Even with marginal soil cover, the IRT green film nonetheless had the greatest DD values (Fig. 2, Table 1). With IRT films, soil-mulch contact is not as critical as with conventional films. IRT films allow more short wave radiation to pass directly through and warm the soil while blocking most light in the PAR range of the spectrum (Liakata et al., 1986; Ngouajio and Ernest, 2004).

Double cropping the IRT green, grey, and IRT brown plastics is undesirable because of their substantial degradation. Although they maintained the critical $>50 \%$ to $60 \%$ cover (Jones and Chapman, 1968; Maelzer, 1986), weed control, water conservation, and other benefits of the plastic mulch are reduced. However, where portions of these mulches remained intact, they lost less of their heating capacity after field exposure compared to the black plastic (Table 3). This is perhaps due to the difference in soil warming mechanisms between the black and IRT plastics.
Decoteau, D.R., M.J. Kasperbauer, D.D. Daniels, and P.G. Hunt. 1988. Plastic mulch color effects on reflected light and tomato plant growth. Scientia Hort. 34:169-175.

Díaz-Pérez, J.C. and K.D. Batal. 2002. Colored plastic film mulches affect tomato growth and yield via changes in root-zone temperature. J. Amer. Soc. Hort. Sci. 127:127-132.

Ham, J.M., G.J. Kluitenberg, and W.J.Lamont. 1993. Optical properties of plastic mulches affect the field temperature regime. J. Amer. Soc. Hort. Sci. 118:188-193.

Hanna, H.Y. 2000a. Black polyethylene mulch does not reduce yield of cucumbers double-cropped with tomatoes under heat stress. HortScience 35:190-191.

Hanna, H.Y. 2000b. Double-cropping muskmelons with nematode-resistant tomatoes increases yield, but mulch color has no effect. HortScience 35:1213-1214.

Hanna, H.Y., P.D. Colyer, T.L. Kirkpatrik, D.J. Romaine, and P.R. Vernon. 1993. Improving yield of cucumbers in nematode-infested soil by double-cropping with resistant tomato cultivar, using transplants and nematicides. Proc. Fla. State Hort. Soc. 106:163-165.

Ibarra, L., J. Flores, and J.C Díaz-Pérez. 2001. Growth and yield of muskmelon in response to plastic mulch and row covers. Scientia Hortic. 87:139-145.

Jenni, S., D.C. Cloutier, G. Borgeois, and K.A. Stewart. 1996. A heat unit model to predict growth and development of muskmelon to anthesis of perfect flowers. J. Amer. Soc. Hort. Sci. 121:274-280.

Jones, F.R. and R.K. Chapman. 1968. Aluminum foil and other reflective surfaces to manipulate the movement of aphid vectors of viruses. Proc. North Central Branch Entomol. Soc. Amer. 23:146-148.

Kasperbauer, M.J. and P.G. Hunt. 1998. Far-red light affects photosynthate allocation and yield of tomato over red mulch. Crop Sci. 38:970-974.

Liakatas, A., J.A. Clark, and J.L. Montheith. 1986. Measurements of the heat balance under plastic mulches. part I. Radiation balance and soil heat flux. Agric. For. Meteorol. 36:227-239.

Maelzer, D.A. 1986. Integrated control of insect vectors of plant virus diseases, p. 483-512. In: G.D. Mclean, R.G. Garrett (eds.). Plant virus epidemics-Monitoring, modeling and predicting outbreaks. Academic Press, New York.

Mugalla, C.I, C.M. Jolly, and N.R. Martin, Jr. 1996. Profitability of black plastic mulch for limited resource farmers. J. Prod. Agr. 9:283-288.

Ngouajio, M. and J. Ernest. 2004. Light transmission through colored polyethylene mulches affects weed populations. HortScience 39:1302-1304.

Ryer, A. 1997. Light measurement handbook. International Light Inc., Newburyport, Mass.http:// www.intl-light.com/handbookthanks.html.

Tarara, J.M. 2000. Microclimate modification with plastic mulch. HortScience 35:169-180.

Waterer, D.R. 2000. Effect of soil mulches and herbicides on production economics of warm season vegetable crops in a cool climate. HortTechnology 10:154-159. 